\title{
Memprediksi Pembelian Kerupuk Kulit Menggunakan Logika Fuzzy Sugeno Pada Home Industri
}

\author{
Parawystia Prabasini Haryoto1, Aryu Tiffany Matondang², Selvi Salsabillah Nasution³, Gading \\ Triswidanto 4 \\ STIKOM Tunas Bangsa PEMATANGSIANTAR ${ }^{1,2,3}$ \\ JL. Jendral Sudirman Blok A, No. 1/2/3 \\ parawystia11@gmail.com ${ }^{1}$, selvisalsabillah@gmail.com ${ }^{3}$,
}

\begin{abstract}
Skin crackers are a very profitable business of skin crackers when run, but many skin crackers entrepreneurs are overwhelmed in calculating the purchase of skin crackers. This study uses the Fuzzy Sugeno Method which is a method used in decision making as well as determining the income of an agency. For that, the Sugeno method is very suitable in solving the problem of determining the purchase of skin crackers.
\end{abstract}

Keywords : Fuzzy Sugeno, purchases, skin crackers

Abstrak : Kerupuk kulit merupakan usaha kerupuk kulit sangat menguntungkan bila dijalankan, tetepi banyak pengusaha kerupuk kulit yang kewalahan dalam memperhitungkan pembelian kerupuk kulit. Penelitian ini menggunakan Metode Fuzzy Sugeno yang merupakan metode yang digunakan dalam pengambilan keputusan seperti halnya menentukan penghasilan suatu instansi. Untuk itu metode sugeno dirasa sangat cocok dalam penyelesaian permasalahan penentuan pembelian kerupuk kulit.

Kata Kunci : Fuzzy sugeno, pembelian, kerupuk kulit

\section{PENDAHULUAN}

Home industri adalah rumah usaha produk barang atau juga perusahaan kecil. Dikatakan sebagai perusahaan kecil karena jenis kegiatan ekonomi ini dipusatkan di rumah. Salah satu yang termasuk dalam home industri ialah usaha Kerupuk kulit, Kerupuk kulit merupakan cemilan satu yang paling banyak diminati karena rasanya yang gurih dan lezat. Dengan banyaknya penyuka kerupuk kulit ini membuat usaha kerupuk kulit sangat menguntungkan bila dijalankan. Banyak sekali distributor kerupuk kulit yang tersebar dihampir semua wilayah Provinsi Sumatera bahkan di Jawa. Provinsi tempat kerupuk kulit Sumatra terkenal dikenal sebagai "kerupuk jangek". Meskipun cracker kulit memiliki kandungan protein yang tinggi, namun kualitasnya lebih rendah dibandingkan daging lainnya produk olahan.

Pembelian krupuk kulit perlu diprediksi dengan akurat, karena hasil prediksi yang akurat sangat penting untuk dapat diambil keputusan yang tepat agar dapat diketahui bagaimana perkembangan pembelian kerupuk kulit ini memang benarbenar dapat menguntungkan.

Penelitian ini menggunakan Metode Fuzzy Sugeno yang merupakan metode yang digunakan dalam pengambilan keputusan seperti halnya menentukan penghasilan suatu instansi. Untuk itu metode sugeno dirasa sangat cocok dalam 
penyelesaian permasalahan penentuan pembelian kerupuk kulit. Penelitian ini bertujuan untuk menghasilkan sebuah sistem pendukung keputusan yang dapat membantu pengusaha dalam menentukan prodiksi kerupuk kulitnya. Metode ini dipilih karena mempunyai aturan berbentuk IF-THEN yang akan dipresentasikan dalam himpunan fuzzy dengan fungsi keanggotaan yang monoton.[1]

\section{METODOLOGI PENELITIAN} berikut :

Dalam rangka menyelesaikan penelitian ini metode yang adalah sebagai

\subsection{Metode Pengumpulan Data}

Metode pengumpulan data dilakukan dengan data penjualan kerupuk kulit dengan melakukan wawancara pada pemilik home industri kerupuk kulit

\subsection{Logika Fuzzy}

Logika fuzzy merupakan sebuah logika yang memiliki nilai kekaburan atau kesamaran (fuzzyness) antara benar dan salah [2]. Dalam teori logika fuzzy sebuah nilai bisa bernilai benar atau salah secara bersamaan namun berapa besar kebenaran dan kesalahan suatu nilai tergantung kepada bobot keanggotaan yang dimilikinya. [3] Dalam logika fuzzy kemungkinan nilai keanggotaan berada diantara 0 dan 1.[4]

\subsection{Fungsi Keanggotaan}

Fungsi keanggotaan yang digunakan dalam perencanaan adalah fungsi keanggotaan linier.

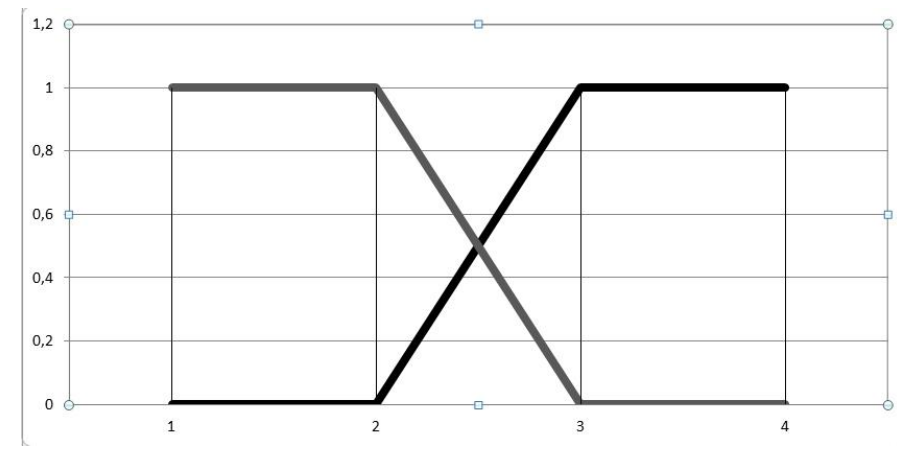

Gambar 1. Kurva Fungsi Keanggotaan Linier

\subsection{Perancangan Logika Fuzzy}

a. Kriteria

Kriteria yang digunakan dalam prediksi pembelian kerupuk kulit menggunakan Fuzzy Sugeno yaitu : 
Tabel 1. Kriteria, Fuzzifikasy dan Domain

\begin{tabular}{|l|l|l|l|l|r|}
\hline \multicolumn{2}{|c|}{ Variabel } & \multicolumn{2}{c|}{ Fuzzy Set } & \multicolumn{2}{c|}{ Domain } \\
\hline a & Barang Keluar & {$[$ Rendah } & Tinggi] & 19500 & 28500 \\
\hline b & Persediaan & [Sedikit & Banyak] & 48000 & 60000 \\
\hline c & Pembelian & [Berkurang & Bertambah] & 500 & 1000 \\
\hline
\end{tabular}

b. Pembentukan Rule

Hasil Rule dalam memprediksi pembelian kerupuk kulit menggunakan Fuzzy Sugeno pada Home Indrusti seperti pada table

Tabel 2. Rule

\section{Rule}

[R1] IF $\mathrm{a}=$ Tinggi and $\mathrm{b}=$ Sedikit THEN e $=800$

[R2] IF $\mathrm{a}=$ Rendah and $\mathrm{b}=$ Sedikit THEN e $=(\mathrm{b}-\mathrm{a}) / 40$

[R3] IF $\mathrm{a}=$ Tinggi and $\mathrm{b}=$ Banyak THEN $\mathrm{e}=600$

[R4] IF $\mathrm{a}=$ Rendah and $\mathrm{b}=$ Banyak THEN e $=750$

\section{HASIL DAN PEMBAHASAN}

Dari hasil wawancara oleh pihak kerupuk kulit diketahui barang keluar = 20000 dan persediaan $=50000$ maka, berapakah jumlah kulit yang harus dibeli.

\section{Penyelesaian}

a : 20000

* ( Tinggi

* ( Rendah

Barang Keluar

$\frac{\mathrm{a}-\mathrm{x}}{\mathrm{y}-\mathrm{x}}: \frac{20000-19500}{28500-19500}: \frac{500}{9000}: 0,055555556$

) $\frac{\mathrm{y}-\mathrm{a}}{\mathrm{y}-\mathrm{x}}: \frac{28500-20000}{28500-19500}: \frac{8500}{9000}: 0,944444444$

b : 50000

Persediaan

* C Banyak

$\frac{b-x}{y-x}$

$: \frac{50000-48000}{60000-48000}$

$: \frac{2000}{12000}$ :

0,166666667

* ( Sedikit

$\frac{y-b}{y-x}: \frac{60000-50000}{60000-48000}: \frac{10000}{12000}$

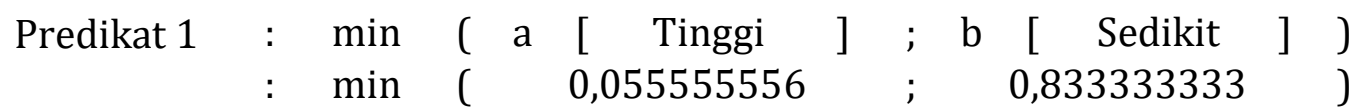

C1 : 800

$\mathrm{C}=(\mathrm{C} 1 *$ Predikat 1$)+(\mathrm{C} 2 *$ Predikat 2$)+(\mathrm{C} 3 *$ Predikat 3$)+(\mathrm{C} 4 *$ Predikat 4 


$$
\begin{aligned}
& \text { Predikat } 1+\text { Predikat } 2+\text { Predikat } 3+\text { Predikat } 4 \\
& C=\frac{(800 * 0,0556)+(750 * 0,8333)+(600 * 0,0556)+(750 * 0,16666667)}{0,055555556+0,833333333+0,055555556+0,166666667} \\
& C=\frac{44,44444444+625+33,33333333+125}{1,111111111} \\
& C=\frac{827,7777778}{1,111111111} \\
& C=745
\end{aligned}
$$

\section{KESIMPULAN}

Hasil prediksi pembelian kerupuk kulit menggunakan logika fuzzy sugeno pada Home Indrusti memperlihatkan nilai akhir pada pembelian sebesar 745 bungkus. Hasil pergitungan prediksi ini hanya untuk mendukung keputusan pada prediksi jumlah penghasilan pada pembelian kerupuk kulit, bukan untuk system pendukung keputusan. Oleh sebab itu untuk pembelian kerupuk kulit tetap tergantung pada pengusaha dan masalah yang dihadapi dan tidak harus menggunakan perhitungan yang ditampilkan.

\section{DAFTAR PUSTAKA}

[1] A. Mulyanto, A. Haris, A. Best, B. Indonesia, and A. Bekasi, "Penerapan Metode Fuzzy Tsukamoto Untuk Menentukan Jumlah Jam Overtime Pada Produksi Barang di PT Asahi Best Base Indonesia ( ABBI ) Bekasi Abstrak," vol. 1, no. 1, pp. 1-11, 2016.

[2] A. Wanto, "Analisis Penerapan Fuzzy Inference System (FIS) Dengan Metode Mamdani Pada Sistem Prediksi Mahasiswa Non Aktif (Studi Kasus : AMIK Tunas Bangsa Pematangsiantar)," in Seminar Nasional Inovasi Dan Teknologi Informasi (SNITI) 3, 2016, vol. 3, pp. 393-400.

[3] S. Wibowo, "Penerapan Logika Fuzzy Dalam Penjadwalan Waktu Kuliah."

[4] I. Fakultas, "Fuzzy Inference System ( FIS ) dengan Metode Tsukamoto dan Mamdani dalam Menentukan Kelayakan Kenaikan Gaji Karyawan,” vol. 1, no. 2, pp. 7-14, 2017.

[5] K. Harefa, T. Informatika, U. Pamulang, and L. Belakang, "PENERAPAN FUZZY INFERENCE SYSTEM UNTUK MENENTUKAN JUMLAH,” vol. 2, no. 4, 2017.

[6] F. Tsukamoto and I. Pendahuluan, "IMPLEMENTASI ALGORITMA FUZZY TSUKAMOTO UNTUK MENENTUKAN JUMLAH PRODUKSI ROTI,” pp. 23-29.

[7] J. Produksi, R. Pada, and C. V Gendis, "Sistem berbasis aturan menggunakan logika fuzzy tsukamoto untuk prediksi jumlah produksi roti pada cv. gendis bakery."

[8] L. P. Ayuningtias, "ANALISA PERBANDINGAN LOGIC FUZZY METODE TSUKAMOTO, SUGENO , DAN MAMDANI ( STUDI KASUS : PREDIKSI JUMLAH PENDAFTAR MAHASISWA BARU FAKULTAS SAINS DAN TEKNOLOGI UNIVERSITAS ISLAM NEGERI SUNAN GUNUNG DJATI BANDUNG )," no. April, 2017.

[9] Y. R. W. U. Kurnia Martha Herdiastuti, Bebas Widada, "IMPLEMENTASI ALGORITMA FUZZY TSUKAMOTO UNTUK MENENTUKAN JUMLAH PRODUKSI ROTI,” pp. 23-29.

[10] D. Bayususetyo, R. Santoso, and Tarno, "KLASIFIKASI CALON PENDONOR DARAH MENGGUNAKAN METODE NAÏVE BAYES CLASSIFIER (Studi Kasus : Calon Pendonor Darah di Kota Semarang)," J. GAUSSIAN, vol. 6, no. 2, pp. 193-200, 2017.

[11] P. Studi, T. Informatika, F. I. Komputer, U. D. Nuswantoro, and L. B. Masalah, "Sistem pendukung keputusan kelayakan pendonor darah menggunakan fuzzy multiple citeria 
decision analysis (f-mcda) timoer dwi hapsoro."

[12] N. R. Sari and W. F. Mahmudy, "Fuzzy Inference System Tsukamoto Untuk Menentukan Kelayakan Calon Pegawai," Semin. Nas. Sist. Inf. Indones., no. November, pp. 2-3, 2015.

[13] Jasri, "Fuzzy Logic Tsukamoto untuk Menentukan Jenis Penyakit Hipertensi dengan Golongan Obat Yang Sesuai," Riau J. Comput. Sci., vol. 4, no. 1, pp. 69-84, 2017.

[14] M. Yusida, D. Kartini, R. A. Nugroho, and M. Muliadi, "Implementasi Fuzzy Tsukamoto Dalam Penentuan Kesesuaian Lahan Untuk Tanaman Karet Dan Kelapa Sawit," Klik - Kumpul. J. Ilmu Komput., vol. 4, no. 2, p. 233, 2018.

[15] M. Mesterjon, Maryaningsih, "Metode Logika Fuzzy Tsukamoto Dalam Sistem Pengambilan," Metod. Log. Fuzzy Tsukamoto Dalam Sist. Pengambilan Keputusan Penerimaan Beasiswa, vol. 9, no. 1, pp. 140-165, 2013. 